\title{
The Trigger Point of Zhen Wu Tang
}

\author{
高木 嘉子
}

\author{
Yosiko TAKAGI
}

\begin{abstract}
要旨 真武湯は少陰虚証の薬方であるが，少陰の葛根湯といわれるほどによく使われ，藤平 健博士により『傷寒論』にもとづく併病理論が明らかにされ, 臨床上その重要性が認識されつ つあるが，慢性疾患の併病の状態の時期に一番多く使われる薬方でもある。しかし，その使用 目標は自覚症状からが殆どであり，本方の腹候は，稲葉文礼氏の『腹証奇覧』に一一腹軟満 にして，之を接せば悸ありて拘攣し，或いは，心下も亦悸して……とある。

藤平健博士の提唱されている真武湯の自覚症状を目標に真武湯を使用した 27 症 例に, 臍左 $1 \sim 2$ 横指附近に, 放散しない痛と抵抗を認め, 症状の改善と共に, 圧痛, 抵抗の軽減また は消退を認めた。また 2 症例には, 圧痛と抵抗を目標に真武湯を使用して, 症状の改善と圧痛 の消退を認めた。それは真武湯の腹候の一つとして有效性があると思われるので報告したいと 思う。
\end{abstract}

\section{緒 言}

今日，文明の発展，経済力の向上により冷えた 水分 (ジュース類, 果物, 飲料水, ビール等) の 摂取や，冷暖房の完備により，水毒と裏寒形成の 素地に囲まれ，陰病の存在は意外に多くなってき ている。少陰病の薬方, 真武湯が頻用される時代 になっているといっても過言ではないであろう。 その使用目標は, 殆どが自覚症状からであり, 腹 候は, 腹力軟にして動悸を触知する, 寺師睦宗博 士は臍の左側 2 横指辺りに圧痛があると述べてい る。真武湯を使用した症例に共通した腹部の圧痛 点（寺師氏と同様）を認めた。

\section{方 法}

対象：平成 1 年 4 月から平成 2 年 6 月までの当 院通院患者27名（男 9 名, 女20名）を対象とし た。
万法 : 藤平健博士の提唱による真武湯の自覚症 状 7 項目 ${ }^{1)}$ を基準に，真武湯を投与した。

(1)歩いていてクラッとする。或はクラッとする

(2)雲の上を歩いているみたいで，何となく足も とが心もとない。或は地にしっかりと足がついて いないよらな感じがする（浮遊感）

(3)誰かと一緒に歩いていると，何で私に寄りか かるのかと言われたりすることがある（寄りかか り)

(4)真っすぐ歩いているつもりなのに横にそれそ らになる(斜行感)

(5)真っすぐ歩こうとするのに横にとれる（斜 行)

(6)坐っていたり，腰掛けていて，ときにクラッ として地震かなと思う（地震感）

(7)眼前の物がサーッと横に走るように感じるめ まい感がある

以上の症状の一つでもあれば真武湯症の併存が

医-開，東京，M. D., Practitioner, Tokyo 
あるとみてよいと博士はいわれる。

圧痛の判定は表 1 のように定めた。

\section{結 果}

表 2 亿示す如く，29例に検討を加えてみた。急 性のめまいを主訴とする“かぜ”の 3 症例（25， 26，27）では，主訴の消退までに $3 \sim 4$ 日圧痛の 消失期間は $5 〜 7$ 日であった。慢性疾患26例に和 いては，主訴または自覚症状の項目の消退までに 平均 2 力月間, 圧痛の消失期間は平均 2.2 力月で あった。また，その消退の仕方は，ある時は症状 の改善に伴ってあとから圧痛も減少，あるいは消 退し，症例 $(7,10,14,15,19)$ のように，厌 痛の減少のあとから症状の改善が認められたもの もあった。症例19に和いては，5週目に圧痛が消 失し, 7 週目に自覚症状項目が消退し, さらに 3 週間続服したらまずくてとても飲む気がしないと いわれ止めた。廃薬後圧痛の出現は認められな い。また症例が少なく，今後検討を要するもので あるが自覚症状の項目の一つもない 2 症例 $(28$,

29）に臍傍圧痛の存在を目標に投与し, 症状の消 退, または軽減と共に压痛も消退した。

腹部は腹力殆どが軟, あるいは中等度より軟で あった。共通して図 1 の如く, 臍の左横 $1 \sim 2$ 横 指に放散しない圧痛と抵抗を認めた。

\section{症 例}

症例 $1 ： 67$ 歳, 女性

夜, 外出した時, 少し寒く感じ, しばらくして 咽がイガイガし，帰宅後 $37.2^{\circ} \mathrm{C}$ あった。寒けと フワフワする感じ，クラッとするめまい感があ り,すぐ床に入った。翌日になっても症状がとれ ず, 来院した。

来院時所見: 体格中等度, 腹力中等度, 脈弦や や沈, 左胸脇苦満 $(+)$, 臍左 2 横指に圧痛 (H), めまい感, フワフワ感, 悪寒, 臍傍圧痛から真武 湯を投与。

経過：3 日目咽頭痛 $(-)$, 悪寒 $( \pm)$, フワフワ 感 $(-)$, 臍傍圧痛 $(+)$ 。

7 日目自覚症状すべて改善され，臍傍圧痛 $( \pm)$ を認めるのみであった。
表 1 真武湯圧痛の判定基準

卅：触れて按じはじめるだけで痛がり，顔をしかめ るもの。

井：軽く按じて痛がるもの。

十：ゆっくり深く按じて痛むもの。

士：ゆっくり深く按じて気持ちよいもの。

一：ゆっくり深く按じても痛みのないもの。

\section{真武湯の圧痛点}

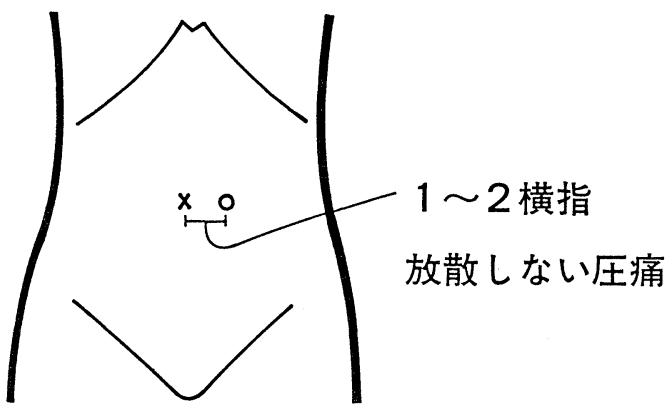

図 1

症例 $2: 71$ 歳, 男性

主訴：月が流れる，目があわる

現病歴： 3 年前, 月を見て月が流れるの飞驚 き，いろいろ検査しても原因不明のまま経過し た。 2 年前, 草花に水をやるとき，小迴りすると 目があわり，体がまわってしまらような感じがす るようになり，治療を受けても何ら効果なく，あ ちこちの病院を転々とし最後の希みをかけで来 院。

来院時：月が流れる，体のまわる感じがし，よ く地震かなと思い，フワフワして地に足がついて いない感じがする，真っすぐに歩こうとしても左 へ行きそらになると，5項目の自覚症状を持って いた。体格やせ型, 蒼白い顔をして年齢より老け て見觉る。冷光は自覚して和らず, 貧血, 嘔吐, 下痱，動悸，頭帽感などなく，頭がうっすら重い (土), 脈沈, 腹力軟, 腹直筋緊張左右 $( \pm)$, 臍左 横 1 横指に放散しない圧痛 $(H)$, 臍下不仁 (H)。

治療预よび経過 : 真武湯を朝に, 八味丸を夕に 服用すること 2 週間，月の流机ることがなくな 
表 2 真武湯の症例

\begin{tabular}{|c|c|c|c|c|c|c|c|c|}
\hline 症 例 & 性別 & 年齢 & 主＼cjkstart訴 & $\begin{array}{l}\text { 嘎状の } \\
\text { 覚 } \\
\text { 目 }\end{array}$ & 圧痛 & $\begin{array}{l}\text { 主訴または } \\
\text { 項の䦔失 } \\
\text { 期間 }\end{array}$ & $\begin{array}{l}\text { 压痛の } \\
\text { 消 失 } \\
\text { 期 }\end{array}$ & 併用薬 \\
\hline 1. & $\hat{o}$ & 71 & めまい & 5 & W & 10週 $(\rightarrow$ & 12週( () & \\
\hline 2. & t & 49 & めまい・耳鳴り & 3 & + & 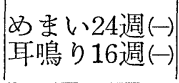 & 24 週( $($ ) & \\
\hline 3. & $\hat{o}$ & 61 & めまい & 2 & + & 2 週( $)$ & 5 週( & \\
\hline 4. & б & 48 & めまい & 3 & $H$ & 17日 () & 17日( $( \pm)$ & \\
\hline 5. & $\delta$ & 65 & 耳鳴り・高血圧 & 1 & $H$ & 14週(土) & 14週( $( \pm)$ & 黄連解毒湯 \\
\hline 6. & ᄒ & 17 & 湿 疹 & 1 & + & 6 週(軽減) & 6 週( $( \pm)$ & 温清飲 \\
\hline 7. & t & 69 & 白 斑 & 1 & + & 14週(軽減) & 2 週( & 温清飲加減 \\
\hline 8 & $\delta$ & 33 & 湿 疮 & 2 & $H$ & 11週(軽減) & 11週( & 桂枝获苓丸 \\
\hline 9. & б & 13 & 湿 疹 & 2 & + & 4 週(軽減) & 4 週( $)$ & 当帰䓎薬散 \\
\hline 10. & t & 17 & にきび & 2 & $H$ & 20週( $( \pm)$ & 16週(土) & 当帰䓎薬散 \\
\hline 11. & & 54 & 左腕の痛み & 4 & H & 6 週(-) & 8 週( $)$ & 治打撲一方 \\
\hline 12. & $\hat{o}$ & 77 & 間歇性跛行 & 2 & + & 4 週( () & 6 週( $\rightarrow$ & 桂枝获苓丸 \\
\hline 13. & t & 62 & 背部痛 & 4 & W & 6 週( () & 12週( $( \pm)$ & \\
\hline 14. & $\hat{o}$ & 65 & 背部寒け & 2 & + & 4 週( () & 2 週(土) & \\
\hline 15. & ᄒ & 36 & 涙 目 & 2 & + & 10週( $( \pm)$ & 6 週( $( \pm)$ & \\
\hline 16. & б & 39 & 胃のもたれ & 1 & + & 3 週( () & 3 週( & \\
\hline & б & 44 & 頻 尿 & 2 & $H$ & 4 週(士) & 6 週(士) & \\
\hline 18. & б & 62 & 残尿感 & 2 & $H$ & 4 週( & 12週(-) & 駆瘀血丸 \\
\hline 19. & $\hat{o}$ & 53 & 腎不全・だるい & 2 & W & 7 週( $(-)$ & 5 週( & 八味丸・五苓散 \\
\hline & $\hat{o}$ & 65 & 腰痛・肩こり & 1 & H & 8 週( & 10週( & 八味丸 \\
\hline & б & 42 & 肩こり・頭痛 & 2 & $H$ & 4 週( & 8 週(士) & \\
\hline & $\hat{o}$ & 65 & 物忘れ & 2 & + & 12週( $( \pm)$ & 8 週( $)$ & 釣藤散 \\
\hline 23. & $\hat{o}$ & 68 & 高血圧 & 2 & H & 16週( & 18週( $( \pm)$ & \\
\hline 2 & t & 52 & 高血圧 & 4 & + & 4 週( () & 12週( () & \\
\hline & t & 66 & めまい・風邪 & 2 & $H$ & 3 日 $(-)$ & 5 日 $( \pm)$ & \\
\hline 2 & t & 60 & めまい・風邪 & 3 & H & 3 日 () & 7 日 & \\
\hline 27 & t & 74 & めまい・風邪 & 2 & $H$ & 4 日 $(-)$ & 7 日 & \\
\hline & t & 53 & 手足のむくみ & 0 & $H$ & 5 週(-) & 9 週( & \\
\hline & $\hat{o}$ & 55 & 乾 癬 & 0 & $H$ & 8 週(軽減) & 6 週( () & \\
\hline
\end{tabular}


$\eta$, 斜行感 $(t)$, 臍傍圧痛 $(+)$ 。

6 週間目め安 $(+)$, 斜行感 $(+)$, 地震感 $( \pm)$, 臍傍圧痛 $( \pm)$ 。

10週間目め柰い(-), めまい感 $( \pm)$, 地震 感 $( \pm)$, 斜行感 $( \pm)$, 臍傍圧痛 $( \pm)$ 。

12週間目めまい(一), めまい感 $(一)$, 地震感 (一)，臍傍圧痛(一)となった。

\section{考案}

以上 2 例ともに，臍の左 $1 \sim 2$ 横指に放散しな い压痛と抵抗を認め，症状の改善または消退によ り圧痛も弱まり, あるいは消退した。1 例目は, 感冒により真武湯の証を現わしたもので，7日で 圧痛は消退した。2 例目は, 慢性に経過したもの で，自覚症状 5 項目が認められ，12週間目には自 覚症状も圧痛も消退した。

古典には，傷寒論の条文に「太陽病，発汗，汗 出不解, 其人仍発熱, 心下悸, 頭眩, 身閏動, 振 振欲擗地者, 真武湯主之」「少陰病二三日不己, 至四五日, 腹痛, 小便不利, 四肢沈重疼痛, 自下 利，其人或欬，或小便利，或不利，或嘔者，玄武 湯主之」と腹証について述べられてはいない。稲 葉文礼氏 ${ }^{2)}$ は腹証奇覧に「腹軟満ニシテ, 之ヨ按 セバ悸アリテ拘攣シ，或イハ，心下モ亦悸シテ， 時々目眩シ，身瞤動シ，或イ八，時々悪寒シ，小 便不利, 或イ八嘔スル者, 又云ウ, 此ノ証, 四支 疼重, 或ハ沈重疼痛スル者間アリ, 其ノ余何病 問ワズ, 前ニ云ウ如ク腹診ヨ詳カニシテ, 現証時 トシテ目眩, 身瞤動シ, 震々トシテ地二擗ント欲 スル者 眼トシテ, 之ヨ用イテ其ノ効有ラザルコ トナシ。

又云ウ, 此ノ証ニシテ, 腹底二寒冷 7 覚ユル者 大イニアリ」と云っているが，圧痛については語 られていない。また，小島明有鄉の聖剂発蘊には ${ }^{3)}$ 「胸状丸ク，大カカリニテ肉习モチ色白ク，ボッ テリスル也，大腹八軟弱ノ中ニ少シク拘攣アリ。 臍辺二至テ附毒を蓄へ，小腹マデ，グサグサシテ
濡ナル者ナリ，此ノ証瞤動甚シケレ八，張籠ノ虎 ノ如ク，顔面 フルル者アリ，或八，身体ユサュサ トシテ, 足ノ蹈ミトメナク，世ニヨイヨイト云様 ナ者アリ」といずれも腹力軟にして少し拘攣があ ると述べられている。藤平健博士は ${ }^{4)}$ 「牌力は中 等度よりや〉軟または軟で，ときそ軽度または中 等度の心悸を認める」といい，矢数道明博士 ${ }^{5)}$ は 「腹部は軟弱でしばしばガスのため膨満してい る」と述べ，寺師睦宗博士は ${ }^{6)}$ 「臍の左外側 2 横 指の辺りに圧痛点を認める」と述べている。

寺師睦宗博士の圧痛点と私の認めた圧痛と抵抗 は，ほぼ一致するように思われる。

\section{結 語}

真武湯の自覚症状 7 項目を目標に使用した患者 に和いて, 臍の左 $1 \sim 2$ 横指の辺りに放散しない 抵抗と圧痛を認めた。また，本湯の投与により， 圧痛の消退, あるいは軽減を認め自覚症状も消退 した。

また，圧痛のみを目標に使った 2 症例でも，症 状の改善と圧痛の消退を認めた。

これを真武湯の圧痛点と決めてよいかどらか は, 皆様の御追試, 検討戴ければ幸いと思う。

謝辞 この発表にあたり御校閱戴きました藤平健先 生に深謝いたします。第42回東洋医学会で発表させて 戴きました。

\section{文 献}

1 ) 藤平 健 : 漢方腹診講座, p.189, 緑書房, 1991

2 ）稲葉文礼：腹証奇覽，p.144, 医道の日本社, 1981

3 ) 小島明有郷 : 日本漢方腹診叢書傷寒論系二, 聖剂 発蕰巻上二, p. 235 , オリエント出版, 1986

4) 藤平 健 : 漢方腹診講座, p.188, 緑書房, 1991

5 ) 矢数道明: 臨床応用漢方処方 解 説, p.295-296, 創元社, 1971

6 ）高山宏世 : 腹証図解漢方常用処方解説, p.152, 三 考塾叢刊, 1988

（1991年 8 月19日受付） 